Національний педагогічний університет імені М.П. Драгоманова

ORCID ID 0000-0003-2258-1988

e.maluh@npu.edu.ua

\title{
ЗАСТОСУВАННЯ ХМАРО ОРІЕНТОВАНИХ ТЕХНОЛОГІЙ ПІД ЧАС НАВЧАННЯ ІНФОРМАТИКИ МОЛОДШИХ БАКАЛАВРІВ
}

Анотація. Стрімкий розвиток інформаційно-комунікаційних технологій вимагає оновлення всіх галузей суспільства, в тому числі й освітньої. Саме тому все більшої уваги приділяється питанням використання хмаро орієнтованих технологій, зокрема проблемі створення хмаро орієнтованого навчального середовища закладу освіти. Вдосконалення сучасних технологій та оновлення програмного забезпечення вимагає від закладів освіти та викладачів постійної зміни систем навчання та програмного забезпечення відповідно до сучасних тенденцій розвитку інформаційнокомунікаційних технологій. Одним із шляхів вирішення цієї проблеми є впровадження у навчальновиховний процес хмаро орієнтованих технологій. Хмаро орієнтовані технології є ефективним засобом наукової діяльності та управління освітнім процесом. В статті проаналізовано доцільність використання хмаро орієнтованих технологій під час навчання інформатики молодших бакалаврів закладів вищої освіти I-II рівня акредитації. Зроблено аналіз означень хмаро орієнтованих технологій, 3'ясовано діяльність усіх учасників навчального процесу та вимоги щодо їх наповнення. Дібрано хмаро-орієнтовані сервіси та додатки, які доцільно використовувати у навчально-виховному процесі закладу освіти. Розглянуто сервіси навчальної взаємодії (віртуальні класи, системи спільної роботи 3 додатками у хмаро орієнтованому середовищі, засоби для організації інтернет-конференцій та ін.). Зроблено детальний аналіз використання дистанційного курсу створеного на безкоштовному сервісі для підтримки навчання Google Classroom. З'ясовано, що сервіс Classroom $є$ сучасним засобом оптимізації роботи викладача під час управління навчальною діяльністю студентів. Ефективності застосування хмаро орієнтованих технологій сприяють високій активності як студентів так i викладачів. Оволодіння хмаро орієнтованими технологіями дозволяє найбільш ефективно організувати навчальний процес.

Ключові слова: хмарні сервіси, хмаро орієнтовані технології, молодші бакалаври інформатики.

Вступ. Освіту, як і інші сфери людської діяльності, не оминув процес інформатизації, що в свою чергу призвело до впровадження сучасних інформаційних технологій у навчальний процес. Особливу увагу слід зосередити на перспективах застосування у навчанні засобів мережі Інтернет. Стосовно цього відбувається перехід певних видів діяльності освітнього процесу до онлайн середовищ, використання яких сприяє поширенню не лише знань, а і способів їх одержання.

Застосування хмарних технологій під час навчання інформатики призводить до надання освітньому процесу більшої гнучкості, відкритості та мобільності. За допомогою хмаро орієнтованих засобів навчання можна суттєво покращити результат навчальної діяльності студентів, за рахунок більшої самостійності під час здобуття знань та опанування навичок набутих в процесі навчання. Здійснюючи вплив на методи, форми та засоби організації навчання, застосування хмарних технологій, тим самим, впливає на методичну систему навчання дисципліни «Інформатика» для молодших бакалаврів закладів вищої освіти I-II рівня акредитації.

Впровадження хмаро орієнтованих технологій у навчальний процес для молодших бакалаврів закладів вищої освіти I-II рівня акредитації надає можливість:

- зменшити витрати на апаратне та програмне забезпечення;

- створювати віртуальні середовища для студентів та викладачів, де студент матиме можливість зайти на домашню сторінку, отримати доступ до необхідних матеріалів навчальних курсів, коментарів та відповідей викладача;

- створювати віртуальні навчальні аудиторії для реалізації можливостей з проведення конференцій, вебінарів, лекцій, семінарів, тренінгів тощо;

- швидкого доступу до інформаційних ресурсів та сервісів Інтернет;

- розширити зв’язок «студент-викладач», «студент-студент» за межами закладу освіти;

- організувати електронний документообіг закладу освіти.

Аналіз останніх досліджень і публікацій. Розробка та використання хмаро орієнтованих технологій в різних сферах діяльності, зокрема і в освітній є актуальним питанням сучасної 
педагогіки. Так, у працях В.Ю Бикова, Ю.В. Горошка, М.І. Жалдака, Н.В. Морзе, А.В. Пенькова, С.А. Ракова, С.О. Семерікова та ін. детально проаналізовано педагогічні підходи до комп'ютеризації та інформатизації навчального процесу та визначено проблеми підготовки фахівців, зокрема й молодших бакалаврів.

Питанням використання хмарних технологій саме в освітній сфері досліджували 3.С. Сейдаметова, С.Н. Сєйтвеліева, Ю.В. Триус, В.М. Франчук, М.П. Шишкіна та ін.

Мета написання статті полягає у виявленні особливостей та з'ясуванні специфіки підготовки молодших бакалаврів під час навчання інформатики в закладах вищої освіти I-II рівня акредитації.

Подання основного матеріалу дослідження. Основними прикладами хмарних сервісів, що використовуються з освітньою метою під час підготовки майбутніх молодших бакалаврів $є$ G Suite та Microsoft Office 365.

G Suite for Education (Рис. 1.) - це wеb-додатки на основі хмарних обчислень, які містять інструменти для студентів та викладачів закладів освіти, що необхідні для ефективного спілкування та спільної роботи [7].

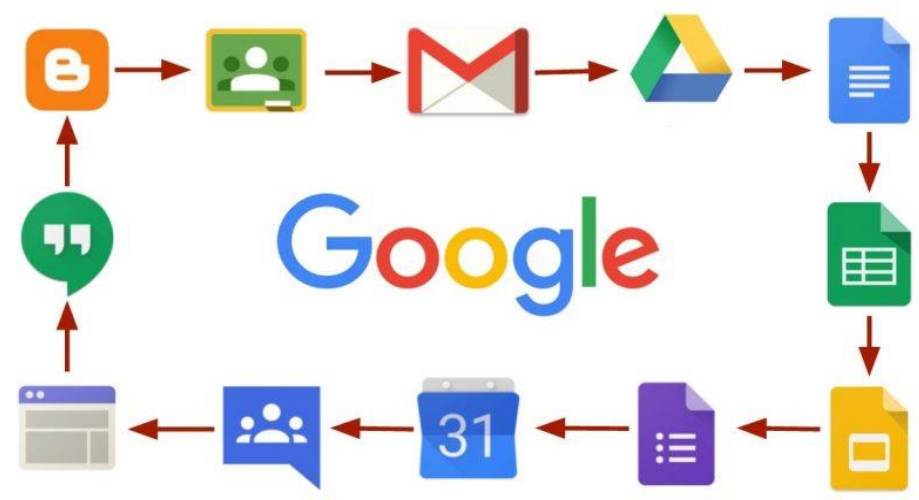

Рис. 1. Основні інструменти wеb-додатку G Suite for Education

Електронну пошту Gmail з G Suite for Education використовують для зберігання даних, пошуку та обміну миттєвими повідомленнями. Календар Google - для складання викладачами та студентами власного розкладу та обміну подіями.

G Suite for Education також містять засоби миттєвого обміну повідомленнями Hangouts, документи Google Docs, таблиці Google Sheets, засоби для створення сайтів Google Sites, презентації Google Slides, сховище даних Google Vault. Всі ці компоненти можуть використовуватись для навчання.

До переваг сервісу G Suite for Education можна віднести такі:

- простота під час використання;

- обов'язкова авторизація;

- безкоштовність;

- адаптація та сумісність (браузери);

- навчання (довідка);

- багатомовність.

Microsoft Office 365 (Рис. 2.) - це хмарне програмне забезпечення компанії Microsoft, що розповсюджується за схемою «програмне забезпечення та послуги» (SaaS - Software as a Services). Назва «Office 365» використовується для продуктів, налаштування яких активуються через Інтернет, наприклад, додатковий простір для збереження даних за допомогою служби SkyDrive [7].

Використовуючи інструменти для спільної роботи, учасники освітнього процесу можуть навчатись 3 будь-якого місця та будь-якого пристрою (електронна пошта, інструменти для відеозустрічей, портал та календарі).

Складовими компонентами Microsoft Office $365 €$ :

- Microsoft Office 365 - використовують для роботи з документами Word, Excel, PowerPoint та OneNote, з можливістю їх перегляду та редагування безпосередньо в браузері;

- SharePoint Online - хмарний інструмент для створення сайтів, порталів, робочих областей для спільної роботи та обміну даними з іншими користувачами;

- Exchange Online - використовують для збереження в хмарі сервіси електронної пошти Outlook, календаря, контакти, забезпечення захисту від вірусів і спаму;

- Lync Online - засоби перевірки присутності та обміну миттєвими повідомленнями, інструменти для аудіо та відеоконференцій і спільного доступу до робочого столу; 
- OneDrive - це онлайн сховище, яке можуть використовувати користувачі разом із обліковим записом Office 365.

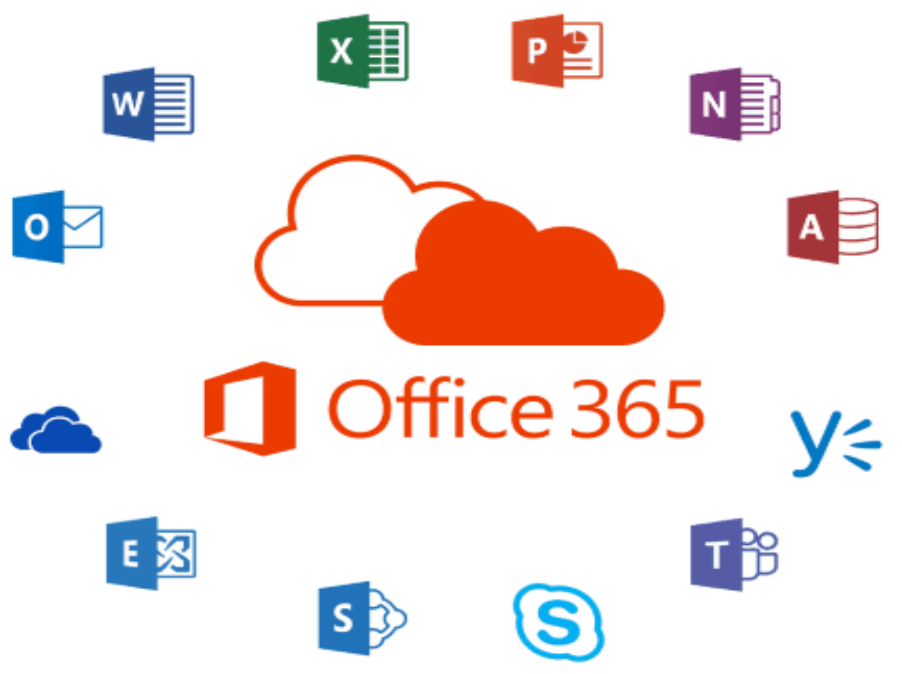

Pис. 2. Основні інструменти сервісу Microsoft Office 365

Таким чином, кожна із згаданих вище компаній, пропонує певний безкоштовний обсяг хмарних послуг для учасників освітнього процесу. Порівняльний аналіз хмарних послуг цих сервісів вказує на те, що Microsoft Office 365 містить більше функціональних інструментів для офісних додатків, у той час як використання G Suite суттєво зорієнтоване на використання додатків користувача та сторонніх розробників, що значно збільшить вирішення навчальних завдань.

Отже, доцільним $є$ застосування саме G Suite як провідного хмаро орієнтованого засобу навчання інформатики майбутніх молодших бакалаврів. Модель використання G Suite [4] під час навчання інформатики студентів наведено на Рис. 3.

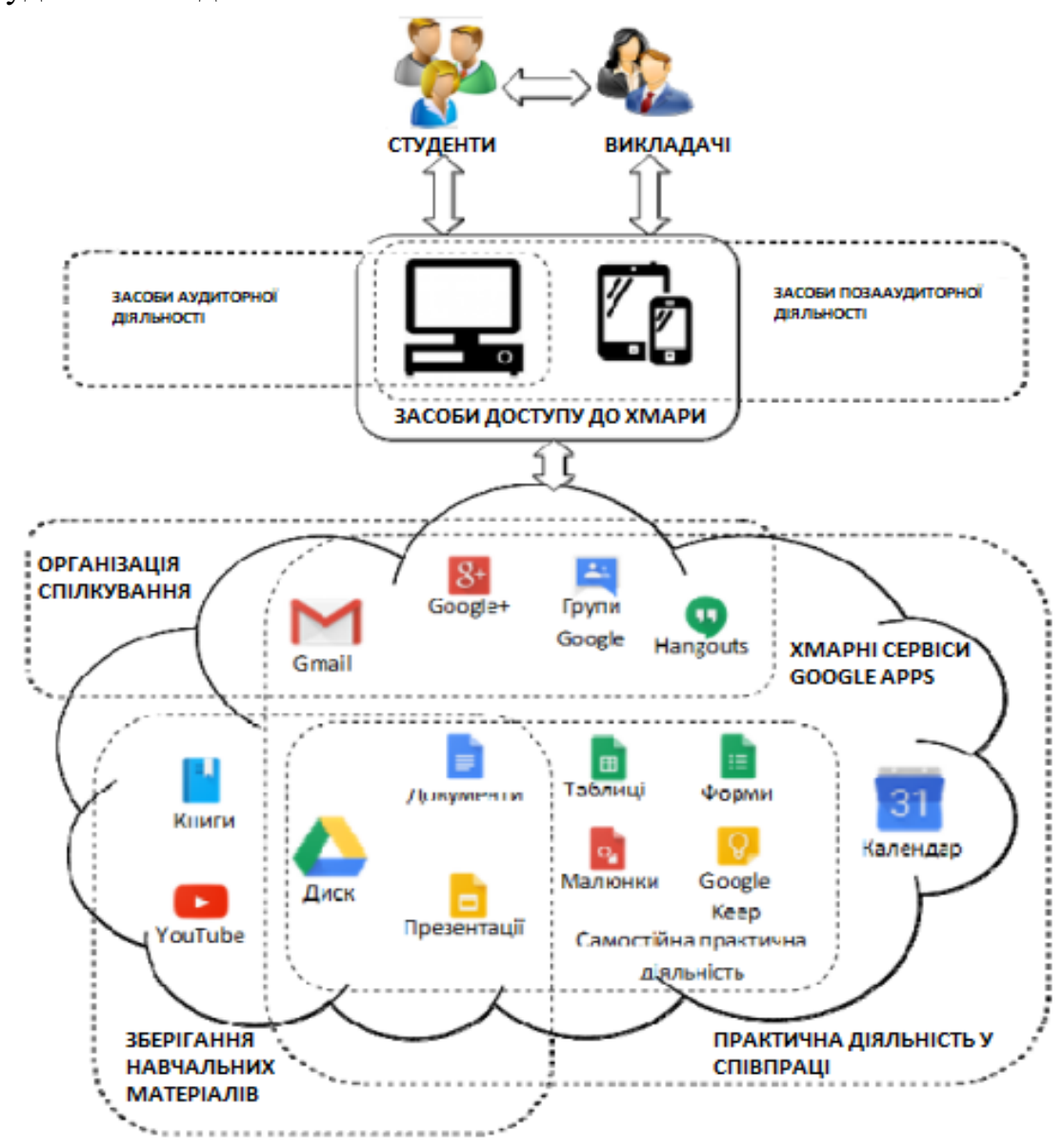

Pис. 3. Модель застосування G Suite у комбінованому навчанні інформатики молодших бакалаврів

Ця модель передбачає використання різноманітних засобів доступу до хмарного сховища та результатів спільної діяльності учасників навчального процесу як під час аудиторної так i 
позааудиторної роботи, що створює умови для реалізації принципів змішаного навчання під час підготовки молодших бакалаврів.

Компоненти платформи G Suite можна використати для проведення дистанційних курсів для студентів, які бажають поглибити свої знання з окремих тем навчальної програми, для тих осіб, що 3 різних причин пропускають навчання, а також для індивідуальної чи групової проектної роботи.

Підсумовуючи вище сказане, зазначимо, що для студентів важливо, щоб спроектоване хмаро орієнтоване середовище містило можливість виконання спільних завдань, мотивувало для подальшої роботи та навчання, а також передбачало всі методи та форми роботи, що необхідні саме для підготовки молодших бакалаврів різних спеціальностей під час навчання інформатики.

В ході дослідження, під час навчання дисципліни «Інформатика (Основи інформатики i обчислювальної техніки)» для студентів спеціальностей 121 «Інженерія програмного забезпечення» та 123 «Комп'ютерна інженерія» Київського державного коледжу туризму та готельного господарства, було розроблено дистанційних курс на безкоштовному сервісі для підтримки навчання Google Classroom (Рис. 4).

$$
\equiv \text { Google Клас }
$$

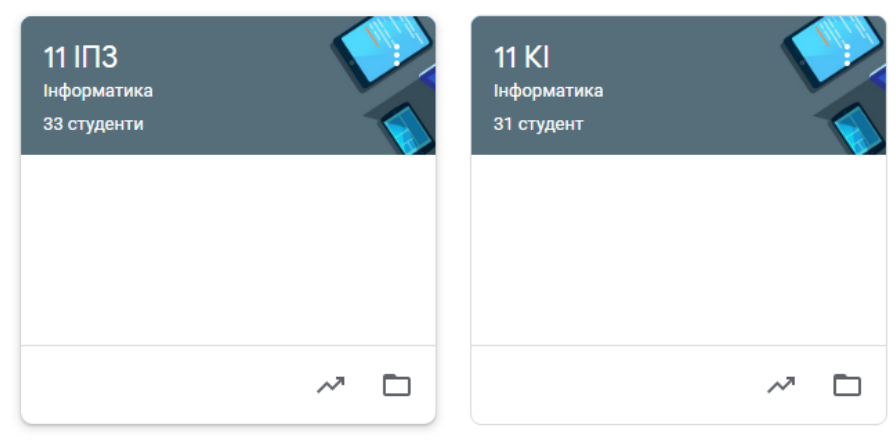

Рис. 4. Головне вікно дистанційного курсу

Google Classroom є сучасним засобом оптимізації роботи викладача під час управління навчальною діяльністю студентів. Використання сервісу дозволяє викладачу швидко створювати, впорядковувати та приймати готові завдання, перевіряти та оцінювати їх, залишати коментарі, давати доручення, прослідковувати їх виконання та робити оголошення [5].

B Google Classroom може використовуватися такі категорії користувачів: учень (студент), вчитель та адміністратор. Вчитель може створювати власні класи, студенти мають можливість приєднуватись до існуючих курсів.

Bci файли, 3 якими працюють користувачі, зберігаються на Google Диск в папку «Клас» (відповідно до назви класу) (Рис. 5). Зазначимо, що під час реєстрації користувача, отримує доступ до диску з необмеженою кількістю використаної пам'яті.

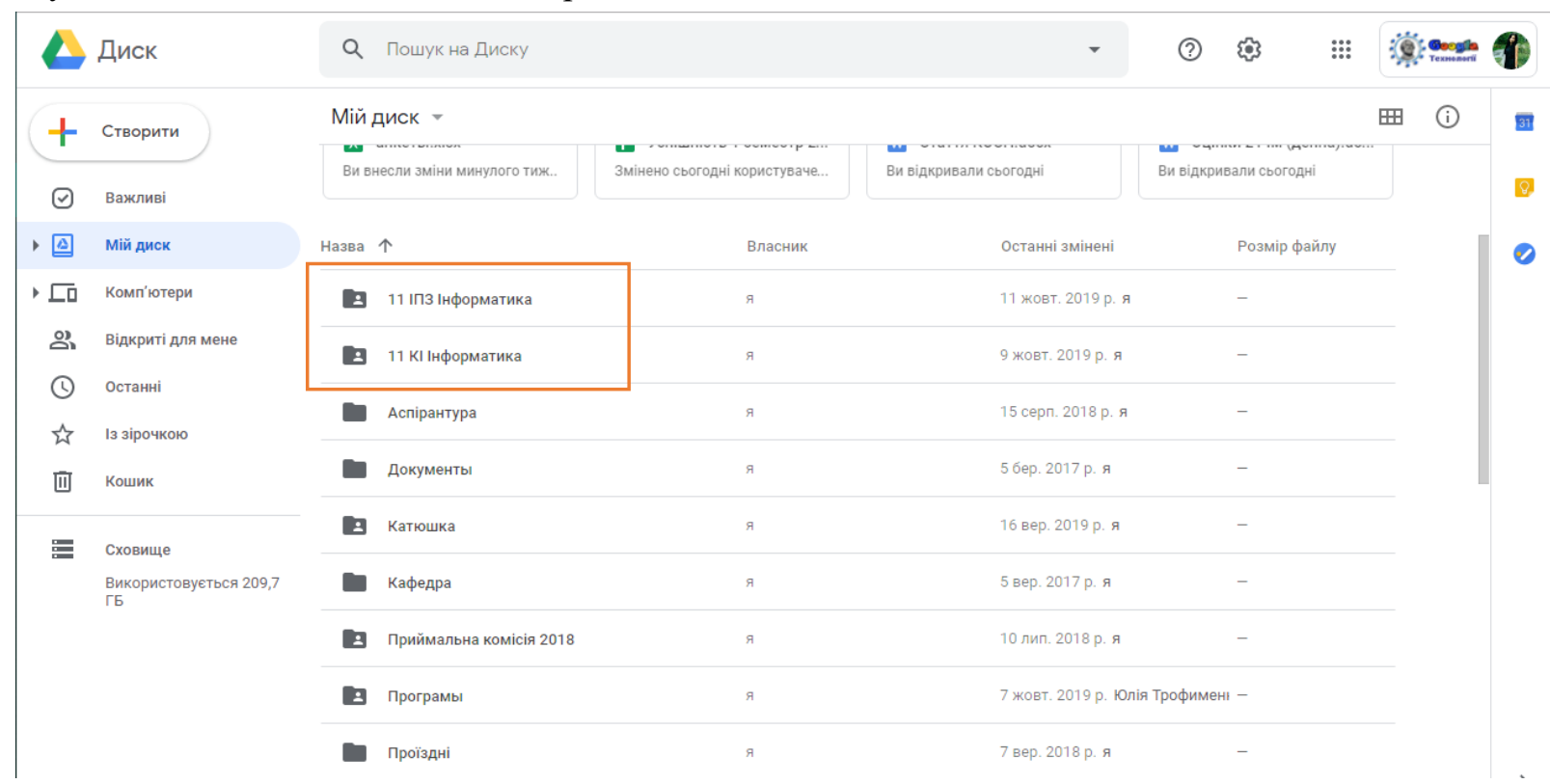

Pис. 5. Файли на Google Диск 
Під час створення завдань 3 використанням Google-документів їх копії автоматично розсилаються всім учасникам, які мають доступ до класу. Створювати завдання, додавати посилання можна як з застосування з Google Диск, так і з використанням мережі Інтернет та відеоматеріалів.

Зручним параметром роботи із завданнями є можливість встановлення дати та часу виконання студентами завдань (Рис. 6). Якщо вчасно завдання не складено, то воно має статус «не виконано».

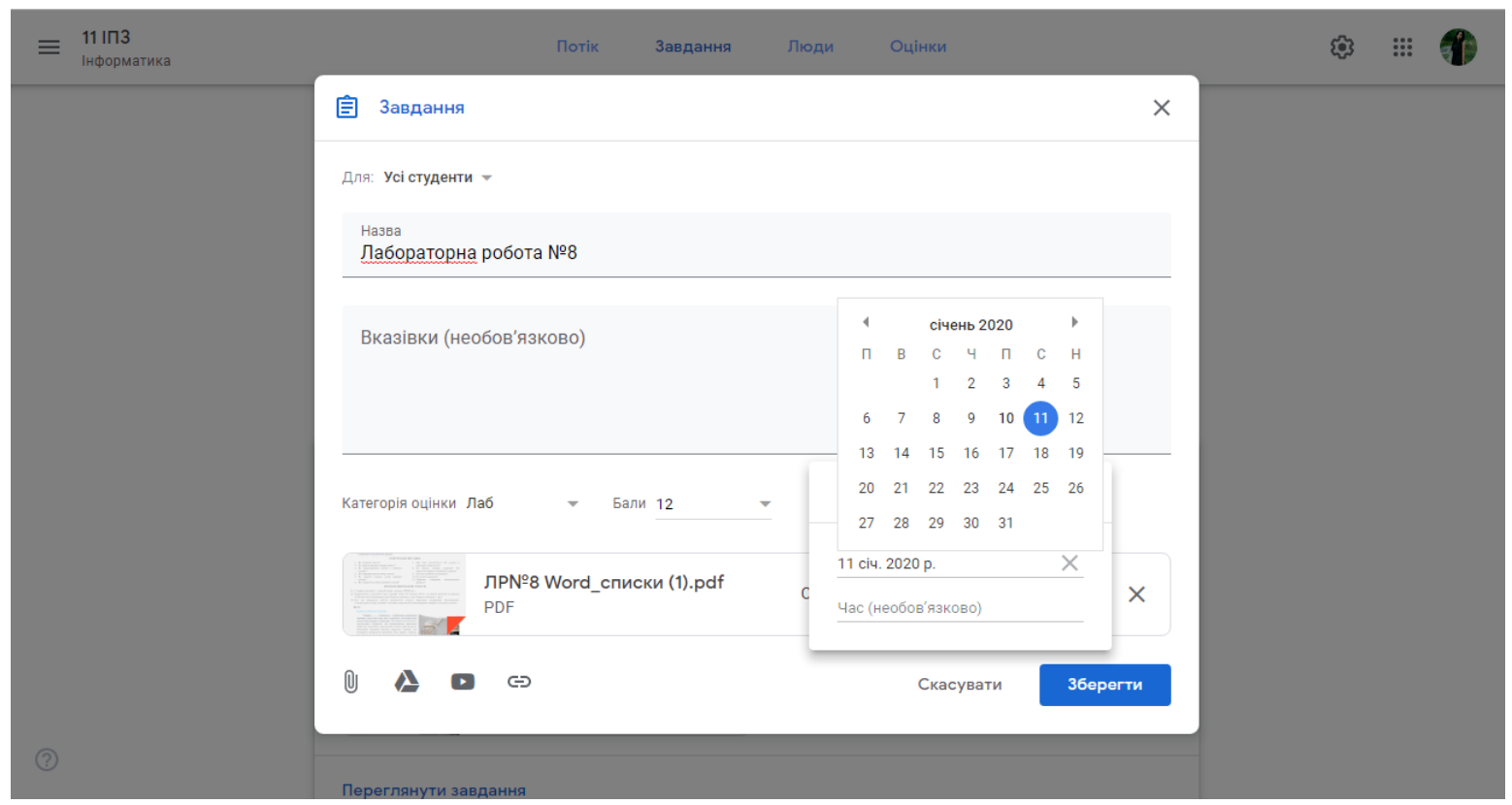

Рис. 6. Встановлення дати та часу виконання студентами завдань

Після виконання завдань викладач перевіряє їх і виставляе оцінки за вказаною системою оцінювання (5-, 12-, чи 100-бальній системі). Результати оцінювання заносяться до електронного журналу (Рис.7), посилання на який надсилаються батькам, так і студентам. Студенти мають можливість лише переглядати оцінки, вносити зміни може лише викладач та адміністратор.

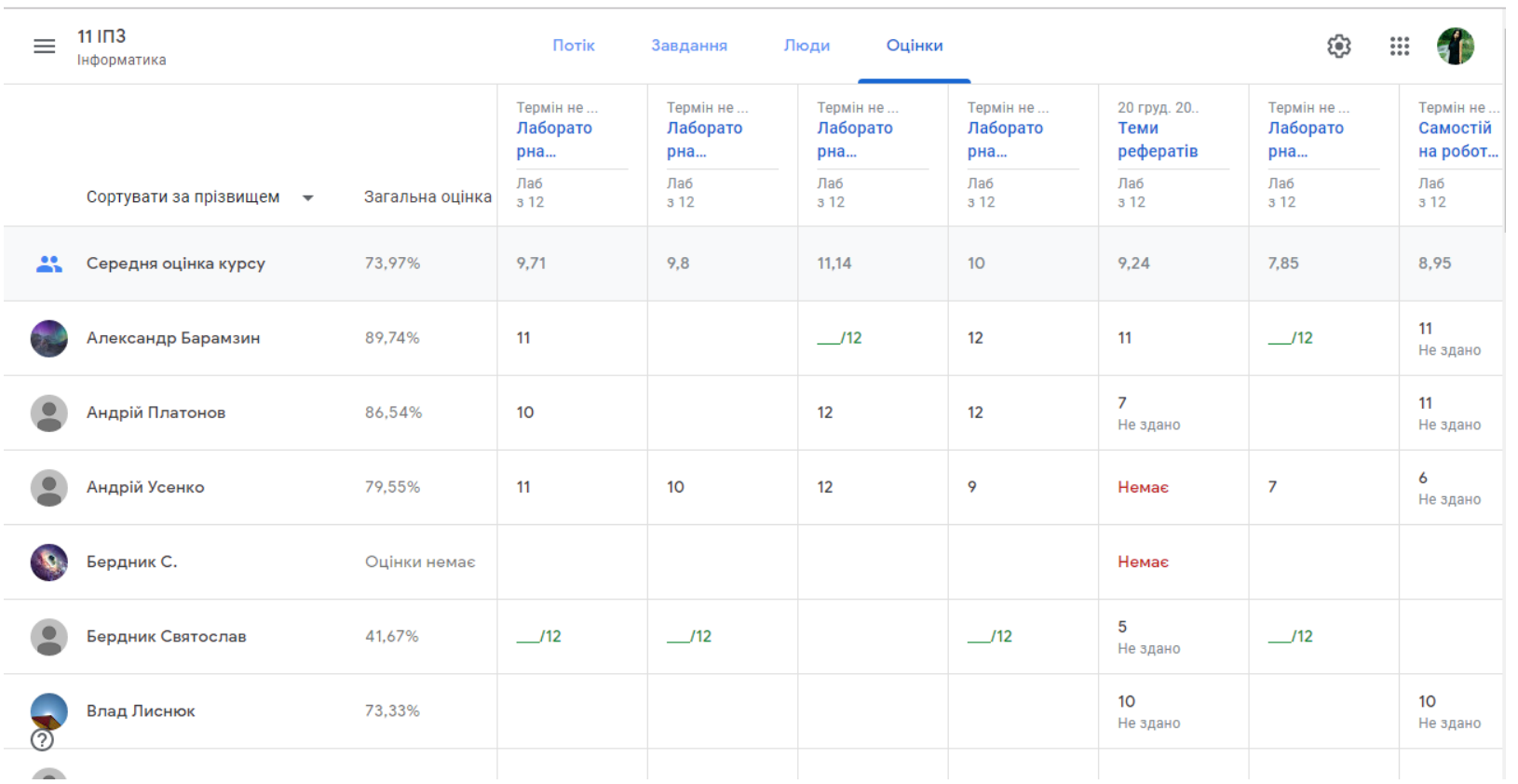

\section{Рис. 7. Електронний журнал}

Для визначення ефективності використання хмаро орієнтованих технологій та рівня засвоєння знань під час навчання інформатики молодшими було розроблено та проведено анкетування серед студентів. Опитування показало, що переважна більшість віддає перевагу навчанню за допомогою хмаро орієнтованих технологій, так як використання розробленого дистанційного курсу допомогло підвищити навчальну діяльність та мотивувати до самоосвіти та опанування нових сучасних хмарних технологій.

Також студентами було зазначено, що використовуючи хмаро орієнтовані технології спостерігається економія навчального часу, розвитку логічного мислення та пам'яті, акцент переміщується на відпрацювання здобутих навичок для особистих потреб. 
Висновок. Використовуючи описані вище хмаро орієнтовані системи, студенти мають змогу суттєво зменшити використання паперових носіїв даних, як наслідок, зосередити увагу, передусім, на зміст навчальних завдань. Цьому також сприятиме закріплення та вивчення навчального матеріалу в режимі онлайн.

Водночас, викладач, що застосовує хмарні технології під час навчання, повинен мати належний рівень підготовки. Використання сучасних хмаро орієнтованих технологій є необхідною умовою для реалізації особистісно орієнтованого навчання, підготовки молодших бакалаврів до подальшого професійного зростання в інформаційному просторі.

Таким чином використання системи Classroom в навчальному процесі $є$ актуальною задачею сьогодення, успішне розв'язання якої безперечно сприятиме підвищенню ефективного навчання.

\section{Список використаних джерел}

[1] Биков В. Ю. Технології хмарних обчислень, ІКТ-аутсорсінг та нові функції ІКТ підрозділів освітніх і наукових. Інформаційні технологї̈ в освіті. №10. 2011. С. 8-23.

[2] Вакалюк Т.А. Вибір хмарної платформи для проектування хмаро орієнтованого навчального середовища для підготовки бакалаврів інформатики. Наукові записки. Випуск 8. Серія: Проблеми методики фізико-математичної і технологічної освіти. Частина 3. Кіровоград: РВВ КДПУ ім. В. Винниченка, 2015. С. 3-7.

[3] Вакалюк Т.А. Модель хмаро орієнтованої системи підтримки навчання бакалаврів інформатики. Інформачійні технології $i$ засоби навчання. 2016. № 6 (56). С. 64-76. URL: http://journal.iitta.gov.ua/index.php/itlt/ article/view/1415/1098 (дата звернення 10.01.2020)

[4] Рассовицька М.В., Стрюк А.М. Модель використання Google Apps у комбінованому навчанні інформатики студентів інженерних спеціальностей. Вісник Дніпропетровського університету імені Альфреда Нобеля. серія «Педагогіка і психологія». Педагогічні науки. 2015. № 1 (9). URL: http://lib.iitta.gov.ua/106474/1/tes_Rassovitska_Stryuk.pdf (дата звернення 10.01.2020)

[5] Розвиток інформаційної компетентності учнів на уроках інформатики з використанням хмарних технологій засобами Google Classroom. URL: http://teacherjournal.in.ua/rozrobky/rozvitokinformatsijnoji-kompetentnosti-uch niv-na-urokakh-informatiki-z-vikoristannyam-khmarnikh-tekhnolo gij-zasobami-google-classroom (дата звернення 10.01.2020)

[6] Шишкіна М.П. Хмаро орієнтоване освітне середовище навчального закладу: сучасний стан і перспективи розвитку досліджень. Інформаційні технології і засоби навчання. 2013. №5 (37). C. 66-80. URL: http://journal.iitta. gov.ua/index.php/ittt/article/view/903/676 (дата звернення 10.01.2020)

[7] Яцько О.М. Хмарні технології у навчанні інформатики майбутніх економістів. Новітні комп'ютерні технології спеивипуск «Хмарні технологї навчання». T. XII (2014). URL: http://lib.iitta.gov.ua/707509/1/\%D0\%AF\%D1\% 86\%D1\%8C\%D0\%BA\%D0\%BE.pdf $\quad$ (дата звернення 10.01.2020)

[8] Франчук Н.П. Використання додатків Office 365 у навчальному процесі. Проблеми інформатизації навчального процесу в закладах загальної середньої та вищої освіти: матеріали Всеукраїнської науково-практичної конференції, 09 жовтня 2018 року. м. Київ. 2018. С. 75-77.

\section{References}

[1] Bykov V. Yu. (2011) Cloud computing technologies, ICT outsourcing and new functions of ICT units of educational and scientific units. Information technology in education. №10. P. 8-23. (in Ukrainian)

[2] Vakalyuk T.A. (2015) Choosing a cloud platform for designing a cloud-based learning environment to prepare Bachelor of Computer Science. Proceedings. Issue 8. Series: Problems of Methods of PhysicalMathematical and Technological Education. Part 3. Kirovograd: RVV KSPU them. V. Vinnichenko, P. 3-7. (in Ukrainian)

[3] Vakalyuk T.A. (2016) Model of cloud-oriented system of support of training of Bachelor of Computer Science. Information technology and training tools. 6 (56). Pp. 64-76. URL: http://journal.iitta.gov.ua/index.php/itlt/ article/view/1415/1098 (accessed 10.01.2020) (in Ukrainian)

[4] Rassovytska M.V., Stryuk A.M. (2015) Model of use of Google Apps in combined education of computer science students of engineering specialties. Bulletin of the Alfred Nobel University of Dnepropetrovsk. Series "Pedagogy and Psychology". Pedagogical Sciences. 1 (9). URL: http://lib.iitta.gov.ua/106474/1/tes_Rassovitska_Stryuk.pdf (accessed 10.01.2020) (in Ukrainian)

[5] URL: http://teacherjournal.in.ua/rozrobky/rozvitok-informatsijnoji-kompetentnosti-uch niv-na-urokakhinformatiki-z-vikoristannyam-khmarnikh-tekhnologij-zasobami-google-classroom 10.01.2020) (in Ukrainian)

[6] Shishkina M.P. (2013) Cloud-oriented educational environment of an educational institution: current 
state and prospects of research development. Information technology and training tools. 5 (37). Pp. 6680. URL: http://journal.iitta.gov.ua/index.php/itlt/article/view/903/676 (accessed 10.01.2020) (in Ukrainian)

[7] Yatsko O.M. (2014) Cloud technologies in teaching informatics to future economists. The latest computer technologies special issue of Cloud Learning Technologies. T. XII URL: http://lib.iitta.gov.ua/707509/1/\%D0\%AF\%D1\%86\%D1\%8C\%D0\%BA\%D0\% BE.pdf (accessed 10.01.2020)

[8] Franchuk N.P. (2018) Use Office 365 applications in the learning process. Problems of informatization of the educational process in institutions of general secondary and higher education: Proceedings of the All-Ukrainian scientific-practical conference, October 09, 2018. Kyiv: NPU named after M.P. Dragomanova, pp. 75-77. (in Ukrainian)

\title{
E. Malyukh
}

\section{APPLICATION OF CLOUD-ORIENTED TECHNOLOGIES IN THE TEACHING OF JUNIOR BACHELORS}

\begin{abstract}
The rapid development of information and communication technologies requires the renewal of all sectors of society, including education. That is why more and more attention is paid to the use of cloud-based technologies, in particular the problem of creating a cloud-based learning environment of educational institutions. Improving modern technologies and updating software requires educational institutions and teachers to constantly change teaching and software systems in accordance with current trends in information and communication technologies. One of the ways to solve this problem is the introduction of cloud-based technologies in the educational process. Cloud-oriented technologies are an effective means of scientific activity and management of the educational process. The article analyzes the feasibility of using cloud-based technologies in teaching computer science to junior bachelors of higher education institutions of the I-II level of accreditation. The analysis of the definitions of cloud-oriented technologies is made, the activity of all participants of the educational process and the requirements for their filling are clarified. Cloud-oriented services and applications have been selected, which should be used in the educational process of the educational institution. Learning interaction services (virtual classes, systems of joint work with applications in the cloud-oriented environment, means for the organization of Internet conferences, etc.) are considered. A detailed analysis of the use of a distance course created on the free service to support learning Google Classroom. It was found that the Classroom service is a modern means of optimizing the work of the teacher in the management of students' learning activities. The effectiveness of cloud-based technologies contributes to the high activity of both students and teachers. Mastering cloudbased technologies allows you to organize the learning process most effectively.
\end{abstract}

Keywords: cloud services, cloud-oriented technologies, junior Bachelor of Computer Science.

DOI 10.31392/NPU-nc.series 2.2020.22(29).23

УДК 373.55

Вікторія Вадимівна Конофольська аспірантка, Національний педагогічний університет імені М. П. Драгоманова ORCID-ID-0000-0003-1632-9778 viktoriakonofolska@gmail.com

\section{ІНТЕГРОВАНІ УРОКИ З ІНФОРМАТИЧНОЮ СКЛАДОВОЮ ЯК НЕВІД'ЄМНА ЧАСТИНА СУЧАСНОЇ ОСВІТИ}

Анотація. Глобальна інформатизація суспільства $є$ однією $з$ домінуючих тенденцій, в тому числі і в освіті. Важливим $\epsilon$ вміння працювати з інформаційними ресурсами та технологіями на уроках та використовувати отримані знання в реальному житті. В умовах освітнього процесу це можливо реалізувати на інтегрованих уроках з інформатичною складовою або спецкурсах.

В статті розкриваються питання міжпредметної інтеграції під час навчання учнів 5-9 класів загальноосвітніх шкіл, а саме актуальності проведення інтегрованих уроків 3 інформатичною складовою. Визначено основні поняття інтеграції освітнього процесу, актуальність та необхідність проведення інтегрованих уроків. Об'єктивно та неупереджено визначено переваги цього підходу. Зокрема, можливість для учнів та вчителів продемонструвати власні досягнення іншими шляхами, окрім традиційних, розкрити потенціал, застосувати творчий підхід. 